\title{
Special aspects of technological entrepreneurship financing at the present stage
}

\author{
Anna Rumyantseva ${ }^{1, *}$ and Viktoriia Bichurina ${ }^{1}$ \\ ${ }^{1}$ Private Educational Institution "St. Petersburg University of Management Technologies and \\ Economics", 44, Lermontovsky Prospekt, 190103 St. Petersburg, Russia
}

\begin{abstract}
Technological entrepreneurship is a new trend of the world economy. The main sources of technological entrepreneurship financing are "business angels", venture capital funds and innovative partnerships. The activation of innovative processes in the scientific and technical sphere becomes an important condition for the highly efficient economy creation. Today the search for innovation financing sources has assumed a special significance, since the innovative economy is characterized by the institutional and business environment mobility and the peculiarity of managing the technological entrepreneurs activities. The modern economy forces to search for new growth areas. From the author's point of view, it is technological entrepreneurship. In this regard, investment partnerships acquire special importance as a way to finance innovation in the country, and also as a way to hedge investments.
\end{abstract}

\section{Introduction}

The modern world with its high speeds and modern technologies are characterized by a constant change in the business environment. In this regard, the analysis of the current standing in the entrepreneurial sphere and the analysis of the main trends in the technological entrepreneurship development become significant. Technological entrepreneurship becomes a "growth area" in the innovation-oriented economies of the world.

The state of entrepreneurship in the country can be judged by different indicators that are analyzed by international organizations and institutions. One of them is the TEA - the index of entrepreneurial activity in the early stages (Total entrepreneurship activity index) that is at the level of 6.27 in Russia as well as in Sweden and Finland, according to the studies results of the GEM International Institute [5]. But this indicator does not show a direct relationship between entrepreneurial activity and GDP per capita, as it does not include a more important study - a business survival characteristics.

According to statistics, in 2016 the level of newly created enterprises in the Russian Federation reduced. So for the period of 2016 first half it was less newly created commercial companies than those that ceased to exist - 218.5 thousand against 242.4 thousand; the organizations official liquidation ratio was 149.2 for 2016 against 67.4 for 2015 per 1000 organizations in Russia [7].

\footnotetext{
*Corresponding author: post_graduate@mail.ru
} 
The main reason, in our opinion, is connected "with a high degree of uncertainty in the economy and negative investment expectations" on the part of business that means a decrease in the possibility of entrepreneurship survival in the current conditions [4].

\section{Materials and methods}

Today the technological entrepreneurship with its serial forms identification is the world economy regularity, and this applies not only to the information technology sphere. It is the topic of serial technological entrepreneurship in the world that is key in discussing the issue of entrepreneurial activity, economic development in general and economic growth in particular.

Technological entrepreneurship (innovative) is a special type of activity that has its own specifics. The classical concept of entrepreneurship implies the independent activities of people aimed at making a profit, that is activities that rely on human and financial resources. There is one more feature in technological entrepreneurship that distinguishes it from ordinary entrepreneurship. It is a new product or new technology. It appears when no previously existing product or technology of its manufacture occurs. This third feature radically changes ideas about entrepreneurship, as it provides innovative technological entrepreneurship with a number of properties.

The basis for ordinary entrepreneurship is production efficiency and cost reduction. With this property, the entrepreneurship focus shifts to mass production, whereas for technological innovation entrepreneurship nothing is more important than the creation of a new product with its subsequent commercialization. It is the basis of competition. In support of the above, there are a number of examples of innovation companies failures only because a product with similar properties had appeared a few months before they appeared on the market. In these examples the cost component is not significant.

Technological entrepreneurship changes the basic law of the "demand breeds supply" economic theory, as it creates a product or technology that has not been claimed or creates new functions of already known and demanded things. It is impossible to estimate the demand in this case.

Another property of innovation entrepreneurship is that appearance of a new product or technology creates a necessity to search for a consumer who does not always realize that he has such a need. Consumer training can be considered as a new direction of entrepreneurship.

The next property of innovation entrepreneurship is the specificity of technological entrepreneurship subjects motivation: income is a tool for creating something new, when for ordinary entrepreneurship income is a fundamental motivation. It does not prevent innovative companies from having a high market capitalization, this is a parallel process. But the original task is still the innovation itself. These companies often work without profit, but with a rapidly growing capitalization. This is the peculiarity of technological entrepreneurship, as a special kind of activity that breaks down many economic laws.

The process of innovative entrepreneurship is difficult to describe and formalize. Let us consider the process of innovative entrepreneurship development in terms of financing, based on the above mentioned features (source of financing; innovative product / technology; technological entrepreneur).

Today we can identify the following sources of innovation financing, each of which can be used at a certain time interval, depending on the stage of innovation:

- grants;

- "business angels";

- $\quad$ venture capital funds;

- investment partnerships;

- $\quad$ public entities. 
The technological entrepreneur formation, his development will be based on the proof of a new idea. As a rule, the source of funding at this stage is a grant, i.e. nonrepayable money. If the concept of innovation is proved, this stage will be passed.

The next stage of such entrepreneurship is a new product creation by the team, i.e. the group of innovators who are engaged in a prototype product with proof of this innovation operability. At this stage there is also grant financing or funding with the help of "business angels". "Business angels" are one of the main elements of the modern international business economy. These are professional investors (individuals and legal entities) investing part of their own finance in innovative companies in the early stages of development - "seed" or "start-up". The overwhelming majority of "business angels" are successful entrepreneurs who have extensive experience in developing their own business. In most cases "business angels" are men (99\%) aged 45 to 65 who have a university degree and managerial experience. Every fifth of them, according to studies of western sociologists, is a millionaire $[5]$.

"Business angels" most often invest in technology and intelligence, preferring high-tech start-ups and Internet projects. They help innovative projects to overcome the period of formation with their own capital, and become the main source of external financing for companies with the potential for rapid growth. "Business angels" can invest not only in the finished project, but also in the idea that it is impossible for an institutional investor (a large financial institution). Many "business angels" advise and provide free assistance to their clients, as they are experts in business.

"Business angels" are professional venture capital individual investors who are focused on supporting start-ups. Unlike classical investors who can pay attention to the newcomer of the business, but this will not become their main strategy. They invest their own money, unlike investors managing other people's funds. "Business angels" always have personal involvement and expertise, investing in projects. They have the ability to make financial decisions more flexibly than venture capital funds. They have broader investment horizons ("long term money"), the execution process is easier and the investment return rate is lower. It is cheaper to attract financing from "business angels" than from other financial institutions. The financial market of "business angels" is more diverse geographically than the venture capital market. "Business angels" prefer to finance high-risk entrepreneurial companies with great growth potential, preferably at the very first stage of their development. Russian "angelic" investments are not developed much. Given the small number of domestic projects, Russian "angels" still prefer start-ups with Russian origin in the US, Europe and Israel. Today there is an association of "Business angels" in Russia consisting of several tens of thousands of professionals [6].

After the innovation working capacity has been proved, the production of a commercially available product takes place, which means that the next method of financing with the help of venture capital funds is needed.

Venture capital funds are companies that invest money, primarily in order to repay their investments. These funds finance only legal entities.

Venture capital funds invest in securities or shares of enterprises with high risk in anticipation of high profit. The share is provided to the fund in standard units - as shares that cannot be immediately exchanged for real money, since these securities are not quoted on the stock market due to the fact that companies are not registered at the exchange. The venture capital fund income is not fixed, it usually invests in a portion of the shares, but not a controlling stake, so that the enterprise does not lose the motivation for development. Whether venture capital fund calculations are justified will become clear only when it leaves it.

It should be noted that the effectiveness of the innovative projects commercialization is also influenced by the innovation infrastructure development in the regions, regional 
innovation potential, the interest of regional authorities and investors in supporting new projects. This is not just about financing and/or stimulating the innovative activity of economic entities itself, including small innovative enterprises affiliated with the leading higher educational institutions of this or that region, but also financing and stimulating organizations that support and provide services to innovative companies. The most effective way to finance a growing economy is leasing. The current policy of import substitution enables the leasing sector to supply equipment for the producing units retooling, which stabilizes both the leasing sector and the economy as a whole [3].

Concerning foreign countries, it should be noted that the venture financing industry is the most developed in the United States and a number of European countries (Britain, the Netherlands, Germany, France, etc.). In Great Britain and the USA, pension funds actively participate in financing innovative projects that, on the one hand, allows innovative enterprises to receive state support, and, on the other hand, enables the funds of these countries to profit in the event of the investment project successful completion. Unfortunately, in Russia non-state pension funds, as a rule, participate in financing low-risk and at the same time low-profit projects, although it is possible to find proposals acceptable in terms of risk and profit margins in the sphere of innovation and high technologies.

In the UK an innovative infrastructure is also developed, including business incubators, innovation centers and technology parks. In France the leading positions in the venture financing market are occupied by banks and insurance companies, in Germany - by banks and private investors. Israel is the recognized leader in the venture financing development, the share of R \& D spending in its GDP is the highest in the world.

The venture financing effectiveness in foreign countries depends largely on the degree of its state support, the legislative framework development, and the state interest in the innovations development. The state provides loans, state guarantees, tax incentives for venture companies, it also takes part in innovative projects co-financing or venture funds creation along with private investors. In our opinion, the same mechanisms should be widely used in Russia.

The advantages of such financing are:

- Venture funds do not need to pay annual or quarterly interest payments.

- Venture capitalists give money for a long time.

- Venture funds do not require liquid liens for investment that start-up companies cannot have.

- Venture fund investors fully assume all financial risks, without requiring any guarantees.

- Venture funds become voluntary business partners with company founders, when financing it.

- Venture funds cannot declare a company bankrupt or bring legal action if it fails to fulfill its obligations on time.

- Venture capital can be used as an additional to medium-term and long-term loan financing.

- Venture capitalists do not change the amount of profitability for the whole period of company development, they do not require to insure their risks.

Due to the fact that venture capital funds put up money only for legal entities, a technology entrepreneur needs to change its status and become a legal entity. After that smallscale production begins. But to enter the mass market with a large volume of production and the product sales, venture funds financing is not enough. At this stage of innovation development, it is necessary to join the innovative partnerships funds (PE Fund). These financial organizations function within the framework of the Federal Law No.335-FZ "On Investment Partnership" dated 28 November, 2011 with the aim of investment projects 
implementing [1]. Having received funding from investment partnerships, the entrepreneur goes to the stage of growth and begins active sales.

Quite often, even this stage is not enough to enable technological entrepreneurship to reach payback. In this case a further option is financing with the involvement of public companies (IPO/Buyout fund) that are joint-stock companies, and carry out their activities under the Federal Law No.99-FZ "On licensing of certain types of activities" of 04/05/2011.

Table 1 shows the main characteristics of the technological entrepreneurship development stages, indicating possible sources of financing, depending on the innovation idea development stages.

Another way to finance technology entrepreneurship is to attract small innovative enterprises to state conversion programs and projects that are the most knowledge-intensive.

There are some limitations, requirements and shortcomings in such financing:

- $\quad$ social importance;

- $\quad$ compliance with specified standards;

- $\quad$ target financing;

- technical difficulties in obtaining;

- $\quad$ small amount of financing.

Along with the shortcomings, there are also advantages:

- implementation if commercial financing is not possible;

- loyalty in payments and terms of the resource usage.

Table 1. Ways to finance innovation.

\begin{tabular}{|c|c|c|c|c|c|}
\hline $\begin{array}{c}\text { Funding } \\
\text { sources }\end{array}$ & Grant & $\begin{array}{c}\text { Grant, } \\
\text { "Business } \\
\text { Angels" }\end{array}$ & $\begin{array}{c}\text { Venture Fund } \\
\text { (VC) }\end{array}$ & $\begin{array}{c}\text { Investment } \\
\text { Partnership } \\
\text { (PE Fund) }\end{array}$ & $\begin{array}{c}\text { Public } \\
\text { Company } \\
\text { (IPO/Buyou } \\
\text { t fund) }\end{array}$ \\
\hline $\begin{array}{c}\text { Product or } \\
\text { technology } \\
\text { characteristics }\end{array}$ & $\begin{array}{c}\text { Innovation } \\
\text { idea }\end{array}$ & $\begin{array}{c}\text { Product } \\
\text { prototype } \\
\text { development }\end{array}$ & $\begin{array}{c}\text { Production of a } \\
\text { commercially } \\
\text { available } \\
\text { product }\end{array}$ & $\begin{array}{c}\text { Sale of ready- } \\
\text { made } \\
\text { innovative } \\
\text { product }\end{array}$ & $\begin{array}{c}\text { Production } \\
\text { and sales } \\
\text { expansion } \\
\text { to reach the } \\
\text { project } \\
\text { payback }\end{array}$ \\
\hline $\begin{array}{c}\text { Technological } \\
\text { entrepreneur } \\
\text { (development } \\
\text { stages) }\end{array}$ & Original idea & $\begin{array}{c}\text { Team of } \\
\text { innovators }\end{array}$ & Start-up & $\begin{array}{c}\text { Company at } \\
\text { growth stage }\end{array}$ & $\begin{array}{c}\text { Public } \\
\text { company }\end{array}$ \\
\hline
\end{tabular}

In the conditions of the modern world turbulence, the state increasingly channels financial flows to the military-industrial complex, where the attraction of innovative small enterprises is more appropriate. State financing can significantly influence the technological entrepreneurship development in the country. But, according to experts, today this method of financing is mainly available only to large enterprises and is no more than $5-10 \%$ of the required volumes.

From the point of view of technological entrepreneurship support, the state can develop production sites of many universities and secondary specialized educational institutions, where small innovative enterprises could be located. Using subcontracting with large enterprises and other economic agents for scientific research, small technological structures can receive the necessary consultations and training. Most universities have a powerful professional and technological base for placing and examining innovations. Creation of an expert council from university specialists in various fields, as well as entrepreneurial scienceintensive structures of different levels, will increase the interest of potential investors to participate in technological entrepreneurship projects that in turn will lead to the growth of small and medium-sized enterprises in the country that form the basis of the economy. 
In foreign countries the following instruments of tax incentives for innovation are applied:

- investment discounts on income tax (Great Britain, Belgium, Denmark, Austria, Australia, Singapore, etc.);

- Research tax credit (USA, Canada, Mexico, Japan, Republic of Korea, Italy, France, Spain, etc.);

- preferential terms for depreciation of fixed assets (Great Britain, Ireland, France, Germany);

- investment tax credit (USA, Philippines);

- investment subsidies (Singapore);

- tax holidays (South Africa, Republic of Korea);

- preferential VAT rates for the sale of goods with an innovative component (Great Britain, Germany, Italy), etc.

In Russia, there are such forms of tax incentives for innovation as [8]:

- exemption from VAT in the R \& D implementation and the enjoyment of rights for the innovation activities results;

- income tax exemptions when accounting for R \& D expenses (raising coefficients);

- exemption from the profit tax of the targeted financing funds;

- application of increasing coefficients of fixed assets depreciation used in scientific and technical activities (accelerated depreciation);

- granting an investment tax credit to taxpayers engaged in R \& D.

Such forms of indirect state stimulation of innovation activities should be widely used, an integrated and systematic approach is needed to assess the appropriateness and effectiveness of applying tax incentives that will help stimulating innovation.

\section{Results}

During the domestic and world economy instability the issues related to the search for the most rational ways to follow the trajectory of sustainable growth and gain a new level of development are being actualized, the qualitative parameters of this development are determined by the postindustrial society innovative type.

Transnationalization of innovative business in western economies leads to its dual position: on the one hand, this type of business develops within national innovation systems, but, on the other hand, it is an element of innovative systems of regional integration associations of countries with developed economies. The latter act as local innovation systems, but the trend towards their convergence and merger in the future will allow to define this trend more precise as a tendency to form a global innovation system. However at the present time, in our opinion, due to the effect of differently directed factors, it is still too early to determine even the contours of such system.

At the same time, strengthening the role of the international influence factor on the economy determines the business development institutions support specifics by western countries. In the developed system of state support for business development institutions at the international level, first of all, innovative and venture ones, the following elements can be distinguished:

- firstly, supragovernment development institutions operating in the space of regional associations (for example, the European Union, OECD, MERCOSUR, NAFTA, etc.);

- secondly, the development institutions established within international organizations of the United Nations (UNCTAD, IMF, MCE, etc.);

- thirdly, the development institutions operating through interstate agreements aimed at creating major investment and innovation projects; 
- fourthly, special structures have been created in the embassies and trade missions departments promoting the innovative business development in the countries of its incorporation;

- fifthly, state bodies supporting the national business development abroad (for example, OPIC in the USA);

- sixthly, chambers of commerce and industry and offices of the national chambers of commerce and industry, carrying out business promotion in all countries, including Russia and China;

- seventhly, informal voluntary associations of large, medium and small businesses representatives for the purpose of forming social capital, establishing informal communication, and personal relations between representatives of national and foreign businesses (business associations);

- eighthly, consulting companies that are supported at the intergovernmental and governmental level, for example, the organization of business consulting for international understanding (BCIU);

- ninthly, charitable foundations.

The structure of business development institutes includes:

- financial institutions, whose activities are aimed at innovative and innovationinvestment business activities financing or co-financing;

- non-financial development institutions, whose activities are aimed at non-financial support and promotion of innovative business activity through, above all, administrative and marketing support.

In the European Union countries there are institutions for the innovative entrepreneurship and venture business development at the national and local levels. According to the report on the results of the European Innovation Assessment application for 2016, innovative leaders with the best national innovation systems are Switzerland, Finland, the United Kingdom, the United States, and Sweden. Outsiders in this report are Bulgaria, Latvia, and Romania. In the second position, Ireland, Austria, Belgium, France, Ireland, Luxembourg, the Netherlands, Slovenia are naturally named as "following the innovations". At the third, middle position, there are countries that are not named above.

In business economies in industrially-oriented countries, including Russia, growth areas are social, youth, environmental, and regional entrepreneurship. This is undoubtedly confirmed in the research works of domestic authors such as V. Gimpelson, A.A. Alekseev, A.E. Karlik, A.N. Kazantseva.

In the economies of innovation-oriented countries, technological entrepreneurship should be considered as the growth area. This is noted by a number of authors considering the entrepreneurship development innovative factor such as V.A. Plotnikov, O.V. Burgonov, N.P. Golubetskaya and others.

Among the main ways to find financing sources, investment partnerships generate interest as a new organizational form.

Investment partnerships consist of two types of members: the managing partner (General Partner) - the one who manages and the LP partner (Limited Partner), who only invests. GP is liable to the full extent of its property, and LP - only of the amount of property contributed and therefore has no right to be included in the selection of projects and evaluate them.

As a rule, one investment partnership has several funded project companies. Investing in several investment projects simultaneously allows to solve one of the most important tasks of any business - hedging risks. Diversifying the investment portfolio in various areas of innovation, the investment partnerships have become unique organizational form with such a fundamental property in Russia and in the world.

The next fundamental property of the investment partnership is the motivation mechanism of the management company within the partnership: short-term motivation $-2 \%$ 
of the current value of assets under management annually; long-term motivation $-20 \%$ of the growth obtained after a successful exit from the investment. In this case, the interests of investors and the management company are completely the same. Such motivation mechanism, coordination of interests within the partnership does not exist in any organizational and legal form of ordinary entrepreneurship.

This business industry (PE) appeared only about 25 years ago and is developing intensively. For comparison, the world banking system assets in 2016 amounted to 20.6 trn. US dollars, and PE assets -3.5 trn. US dollars and the growth rate is much larger than the banking system [6].

Thus, this form of financing organization allows to combine financial and organizational efforts of several participants for investing in risky projects or projects requiring large investments. The introduction of the investment partnerships institute will contribute to the creation of legal conditions, primarily for the development of an innovative economy, the implementation of business projects in the innovation sphere, the activation of collective investment activities of Russian and foreign investors.

\section{Conclusions}

Technological entrepreneurship becomes a "growth area" in the innovation-oriented economies of the world. This indicates a new phase in the civilization development, where the main products are information and knowledge; the phenomenon of technological innovation entrepreneurship changes the business economy model, its management mechanism, including methods and tools, giving it new fundamental properties, forming the modern economy core; the development of investment partnerships network and venture capital should be viewed simultaneously with the solution of the problem of small and medium-sized businesses technological re-equipment in this area that is the main task facing the modern Russian economy. In this regard, the experience of Germany should be taken into account, where these costs are borne by the state; technological entrepreneurship becomes a bright feature of the future innovative-oriented economy of Russia.

\section{References}

1. Federal Law dated 28.11.2011 No.335-FZ “On Investment Partnership”, CL RF 49, 1 (2011)

2. RF Government Resolution dated 8 December 2011 No. 2227-p "On Strategy of Innovation Development of Russian Federation for the period until 2020", CL RF 1, art. 216 (2011)

3. O. Aleksandrova, E. Ivleva, V. Sukhacheva, A. Rumyantseva, E3S Web of Conferences 33, 03057 (2018) doi.org//10.1051/e3sconf/20183303057

4. URL: https://www.vedomosti.ru/economics/articles/2015/12/24/622281-vzglyadekonomistov-chego-opasatsya-i-nadeyatsya-2016

5. URL: http://www.gemconsortium.org/country-profile/104

6. URL: http://gtmarket.ru/ratings/global-competitiveness-index/info

7. URL:

http://www.gks.ru/wps/wcm/connect/rosstat_main/rosstat/ru/statistics/enterprise/refor $\underline{\mathrm{m} / \#}$

8. A. Rumyantseva, Transactions of St. Petersburg University of Management Technologies and Economics 2, 41-52 (2015) 